\title{
茶園雑 草防除の現状と問題点
}

\section{一一静岡県を中心として——.}

\author{
小幡兼男 静岡県茶業試験場
}

Kaneo OватA*: Present Status and Some Problems of Weed Control in Tea fields

\section{1. は しがき}

わが国におけるチャの栽培面積は，1970年ころから活 発な需要にささえられて増加を続けたが，近年，㪘好の 多様化に伴う他飲料の台頭に影響され需要が停滞してい ることもあって，伸びていない。

1985年の全国の茶園面積は $62,000 \mathrm{ha}$ であり，そのうち 静岡県が $36 \%$ 占めている。

生産量は, 1986年全国で93, $600 \mathrm{t}$ であり，そのうち静 岡県が約 $50 \%$ に相当する $46,400 \mathrm{t}$ を生産している。

わが国で生産する茶の殆どは蒸製緑茶であり，世界的 にみてこの蒸製緑茶を飲用する国は他にない。そうした ことから，わが国の茶の輸出は少なく，1,800 $\mathrm{t}$ 程度が アメリカ等に輸出されているに過ぎない。反面, ウーロ
ン茶を始めとして紅茶, 釜炒り緑茶の輸入量は増加し 1985年には23, $000 \mathrm{t}$ に達している。ことに半醱醉茶（ウ 一ロン茶, 包種茶）の輸入量は年ごとに増加する傾向で ある。このような傾向はさらに続くとしても，古来から， 深い文化に根づいたわが国の緑茶に取ってかわるような ことはないと考えるが, 農作物輸入自由化の情勢の中に あって，茶だけがその埒外にあるものではない。加えて， 価格の低迷と生産資材の高騰によって, 茶業経営は極め て撖しい情勢に入ったと言わざるをえない。

今後は安価な良質茶を供給することが必要であり，そ のためには, でき得るかぎり生産費低減を図るなかで, 良質茶の生産が可能な経営を確立することである。幸い チャの栽培においても耕うん，施肥，気象災害防止，さ らには収穫作業等の面で機械化, 装置化が進んでいるが,

第 1 表 時期別茶園雑草発生状況（静岡県牧之原）(1949）（青野ら）

\begin{tabular}{|c|c|c|c|c|c|}
\hline 時 期 & 優生雑草 & 次優生雑草 & 広生雑草 & 散＼cjkstart生 & 希生雑草 \\
\hline $1 \sim 4$ 月 & スズメノカタビラ & 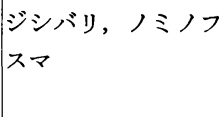 & ムラサキカタバミ & $\begin{array}{l}\text { ヤブタビラコ, ノボロギク, ヨモギ, ヒ } \\
\text { メジョオン, カタバミ, タネツケバナ, } \\
\text { ハコベ }\end{array}$ & $\begin{array}{l}\text { ヤェムグラ, イヌノ } \\
\text { フグリ, ノミノッズ } \\
\text { リ等 } 22 \text { 種 }\end{array}$ \\
\hline $5 \sim 6$ 月 & タニソバ & イヌタデ & $\mid \begin{array}{l}\text { ヒメジョン, ツュク } \\
\text { サ, カラスビシャク }\end{array}$ & $\mid \begin{array}{l}\text { ジシバリ, ヘクソカズラ, カタバミ，ム } \\
\text { ラサキカタバミ, ヤブマメ, メヒシバ }\end{array}$ & 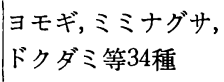 \\
\hline $7 \sim 8$ 月 & メヒシバ & $\begin{array}{l}\text { イヌタデ, タニソ } \\
\text { バ, カヤツリグサ }\end{array}$ & $\mid \begin{array}{l}\text { ジシバリ, ヒメジョ } \\
\text { オン, カタバミ, ッ } \\
\text { ユクサ }\end{array}$ & $\begin{array}{l}\text { ダンドボロギク, ヘクソカズラ, ウリク } \\
\text { サ, コニシキソウ, ヤブマメ, ムラサキ } \\
\text { カタバミ, ザクロソウ, ドクダミ, カラ } \\
\text { スビシャク }\end{array}$ & $\begin{array}{l}\text { ノボロギク,エノキ } \\
\text { グサ, エノコログサ } \\
\text { 等37種 }\end{array}$ \\
\hline $9 \sim 10$ 月 & ザクロソウ & カヤツリグサ & $\begin{array}{l}\text { ヘクソカズラ, ウリ } \\
\text { クサ, ヤブマメ, コ } \\
\text { ニシキソウ, イヌタ } \\
\text { デ, メヒシバ }\end{array}$ & $\begin{array}{l}\text { ジシバリ, ダンドボロギク, キツネノマ } \\
\text { ב゙, トキワハゼ, コミカンソウ, カタバ } \\
\text { ミ, カワラケツメイ, タニソバ, ツュク } \\
\text { サ }\end{array}$ & $\begin{array}{l}\text { トキンソウ, ヒンジ } \\
\text { ガヤツリ, トコロ } \\
\text { 等29種 }\end{array}$ \\
\hline $11 \sim 12$ 月 & ノミノフスマ & スズメノカタビラ & $\begin{array}{l}\text { ジシバリ, ヤブタビ } \\
\text { ラコ, ウリクサ, ホ } \\
\text { ウコグサ, カタバミ, } \\
\text { ヤブマメ, ザクロソ } \\
\text { ウ, メヒシバ }\end{array}$ & $\begin{array}{l}\text { ジシバリ, ヤブタビラコ, ホウコグサ, } \\
\text { ウリクサ, メヒシバ, ザクロソウ, ヤブ } \\
\text { マメ, カタバミ }\end{array}$ & \begin{tabular}{|l} 
ナズナ, キランソウ, \\
ミミナグサ \\
等29種
\end{tabular} \\
\hline
\end{tabular}

* Shizuoka Tea Experiment Station 
なお $10 \mathrm{a}$ 当り作業時間は百数十時間を要し, 生産費も 30 数万円を要しており，一層の機械化，装置化による省力 化が必要である。

ここでは，今なお茶園管理作業時間の十数\%を占める 除草作業について，その現状と問題点について論じてみ たい。

\section{2. 発 生 雑 草}

\section{（1）発生雑草の推移}

茶園における発生雑草の草種, 発生程度については 1949年〜1950年に青野らが，1969年〜1970年に小幡が静 岡県牧之原地方で行った調査結果がある。それによると 青野らの調査結果では, 草種は50科187種であり, その後 20 年を経過した小幡による調査結果では 26 科 54 種であっ た。青野らの調査した1950年当時は，いわゆる戦後と称 された食糧難時代であったので，茶園の管理も極めて悪 く，正常な茶園管理であれば発生しないであろう雑草が, 数多く発生していたことによるものと思われる。そのよ うなことから20年の経過により雑草数は減少の傾向を示

\section{している。}

\section{（2）草種別発生量, 発生消長}

1970年当時の調査によれば，時期別の草種と発生程度 は第 2 表のとおりで, 1 月〜 2 月にかけての比較的雑草 の少ない時期には, ハコベの占有度が大きく, 次いでス ズメノカタビラ，スズメノテッポウ，ノミノフスマが多 く, ホトケノザ, カタバミ,ミミナグサ, イヌタデなど が広く散見される。

5 月になると, イヌタデが優生し, 次いでハルタデ, タニソバなどタデ科雑草が多くなる。この頃になると， それまで優生であったハコべは次第に占有度を下げるが， 依然として生存し，またカタバミ，ノミノフスマ, スズ メノテッポウなど冬期占有度の高かった雑草と, メヒシ バ，タニソバ，ツユクサなど夏雑草が広く散見され，冬 雑草と夏雑草の交替の時期にあたる。

6 月〜 9 月にはメヒシバが優生し, とくに梅雨の明け る頃から次第に占有度を高める。次いでハルタデやハコ ベなど冬春雑草が少なくなってスベリヒユ，カヤツリグ サ, コゴメガヤツリが占有度を高め, 盛夏には春雑草の

第 2 表 月別茶園雑草発生状況（静岡県牧之原）（1969～1970）（小幡）

\begin{tabular}{|c|c|c|c|}
\hline 月 & 生 & 優 & 広 \\
\hline 1 & ハコベ & スズメノカタビラ, ノミノフスマ & $\begin{array}{l}\text { ホトケノザ, スズメノテッポウ, ドクダミ, ヒメムカショモギ, } \\
\text { タビラコ }\end{array}$ \\
\hline 2 & ハコベ & $\begin{array}{l}\text { スズメノカタビラ, ノミノフスマ, スズメ } \\
\text { ノテッポウ }\end{array}$ & $\begin{array}{l}\text { ジシバリ, カタバミ, ミミナグサ, ノゲシ, ホトケノザ, タネ } \\
\text { ツケバナ }\end{array}$ \\
\hline 3 & ハコベ & $\begin{array}{l}\text { スズメノカタビラ, スズメノテッポウ，ノ } \\
\text { ミノフスマ }\end{array}$ & ニガナ, アレチノギク, ホトケノザ, ナズナ, カタバミ \\
\hline 4 & ハコベ & ノミノフスマ, スズメノカタビラ & $\begin{array}{l}\text { ミミナグサ, タネツケバナ, イヌタデ, スズメノテッポウ, 八 } \\
\text { ルタデ, タビラコ, ムラサキカタバミ, ヒメムカショモギ, ホ } \\
\text { トケノザ }\end{array}$ \\
\hline 5 & イヌタデ & ハルタデ，ハコベ，タニソバ & $\begin{array}{l}\text { メヒシバ, スズメノテッポウ, カタバミ, ノミノフスマ, タニ } \\
\text { ソバ, ツュクサ }\end{array}$ \\
\hline 6 & メヒシバ & ハルタデ，ハコベ & $\begin{array}{l}\text { イヌタデ, ツユクサ, カタバミ, スベリヒュ, スズメノテッポ } \\
\text { ウ, スズメノカタビラ, エノコログサ }\end{array}$ \\
\hline 7 & メヒシバ & $\begin{array}{l}\text { スベリヒユ, カヤツリグサ, イヌタデ，八 } \\
\text { ルタデ }\end{array}$ & $\begin{array}{l}\text { コゴメガヤツリ，ツユクサ，エノキグサ, カタバミ, ノビエ, } \\
\text { ハコベ }\end{array}$ \\
\hline 8 & メヒシバ & スベリヒユ, ツユクサ & $\begin{array}{l}\text { ニワホコリ, カヤッリグサ, ハルタデ, カタバミ, コゴメガヤ } \\
\text { ツリ, エノキグサ, エノコログサ, キツネノマゴ }\end{array}$ \\
\hline 9 & メヒシバ & コゴメガヤツリ & $\begin{array}{l}\text { ハルタデ, コニシキソウ, カタバミ, エノコログサ, ニワホコ } \\
\text { リ, ツユクサ, イヌタデ, アキメヒシバ }\end{array}$ \\
\hline 10 & アキメヒシバ & ハコベ & タニソバ, ニワホコリ, ノミノフスマ, スズメノカタビラ \\
\hline 11 & ハコベ & スズメノカタビラ & ノミノフスマ, アキメヒシバ, ヒメムカショモギ \\
\hline 12 & ハコベ & スズメノカタビラ, ノミノフスマ & スズメノテッポウ, ホトケノザ, タビラコ, ヒメムカショモギ \\
\hline
\end{tabular}


残りとニワホコリ, カヤッリグサ, コゴメガヤッリ，エ ノコログサ, エノキグサ, キツネノマゴなど夏雑草が広 く散見されるようになるが, 晚夏にはアキメヒシバが発 生しはじめ夏雑草は衰弱し広く散見されるようになる。

10月にはアキメヒシバが優生し, 次いで冬雑草のハコ ベが次優生になると同時に，ノミノフスマやスズメノカ タビラがタニソバやニワホコリなど夏雑草の残りに混じ って広く散見されるようになる。

11月〜12月はハコベが優生し, 次いでスズメノカタビ ラ, ノミノフスマなどが次優生となり, ホトケノザ, カ タバミ、ミミナグサ，ヒメムカショモギなどが広く散見 されるようになる。

一方，20年を遡った1950年当時も青野らの調査結果に よれば，夏期はメヒシバが優生し，カヤツリグサ，タニ ソバなどが次ぎ, 春にはタニソバ, イヌタデなどが優生 していた。このことは, 茶園の除草の対象となる強害雑 草は，20年の隔たりがあっても変っていないことを示し ている。しかし，1950 年当時に比較して 1970 年当時は ジシバリ，ムラサキカタバミ，カラスビシャクなど宿根 性雑草が減少していること, さらに, ヤブマメ, ヘクソ カズラなど蔓性雑草が減少していることは茶園の中耕, 敷草など管理作業の濃密さの変化を物語るものといえよ 亏。

\section{3. 茶園のうね間管理と雑草害}

チャの植栽間隔は, 平坦地を含めて $15^{\circ}$ 以内の傾斜地 までは，らね間 $1.8 \mathrm{~m}$ ，株間 $0.3 \mathrm{~m}$ の単条に植え， $15^{\circ}$ 以 上の傾斜地ではうね間をやや狭く植えるのが通常である。 したがって, 定植後 $4 \sim 5$ 年目までの幼木期は, うね間 の裸地部分が広く雑草の繁茂も旺盛なため, 樹高の低い チャが遮蔽されて成育が阻害されるが, チャが生長し成 木期に入るとうね間の裸地部分は $30 \mathrm{~cm}$ 程度に狭くなっ て日光も入りにくくなるため, 雑草の発生は比較的少な くなる。加えて, 茶園には種々の目的から山草をうね間 に敷いてマルチする習慣があり,さらに施肥に伴って年 数回行なわれる浅耕や中耕によって成木園での雑草は非 常に少なくなる。

以上のように, 茶園の雑草の発生とうね間管理は樑い 関係を持っているので, 茶園のうね間管理の状況につい て触れておきたい。

\section{(1) マルチの目的}

1) 土壤理化学性の改善

チャが十分生育するための土壌条件は, 根群の生育を

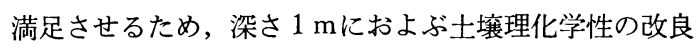
が必要になる。ところが既成園においては, 媣層士壤の
改良は行ないにくいので, 毎年 8 月下旬に行なわれる深 耕と稻わら, 山草のマルチによって徐々にではあるが表 層の透水性の改良や酸性化の緩和, 塩基の溶脱を防ぐこ とができ腐埴含量，有効態りん酸等も增加する。

2）土壤水分の調節

定植間もない幼木期においては, 土壤の乾燥によって 根ばりが悪くなり生育が阻害されるが，マルチすること によって, 水分消費量は半分程度に減少する。

3）地温の調節

作物の生長, 光合成産物の蓄積, 転流には温度条件が 影響することが知られているが，チャの場合においても 高気温, 低地温および長日条件のもとで樹体の生長ない し炭水化物の蓄積, 転流を促進することが解明されてい る。山草などをマルチすることによって，地温は日中低 温に夜間高温に保たれることになる。

4）傾斜地での土壊侵蝕防止

傾斜地茶園の幼木期や一部で行なわれている縦うね型 式の茶園では, マルチが十分に行なわれない限り土壌侵 蝕が激しく栽培が不可能となる。

5) 雑草の発生防止

茶園における稲わらや山草によるらね間マルチは, 本 来前述したような目的をもって行なわれるべきものであ るが, 雑草防止を第一義的に考えて行なわれているのが 実態である。しかし，マルチによって優生雑草であるメ ヒシバ, ハコベ, カヤッリグサ, タデ類などの雑草は発 生を大幅に減少させることができるが，いくつかの宿根 性雑草やマルチのできない株元からの発生は防ぐことが できず，マルチによって完全に雑草を抑制することはで きない。

\section{（2）浅耕および中耕}

茶園の施肥は, うね間に施し直ちに中耕して土と混ぜ るので年数回にわたる中耕と 8 月中旬の深耕が行なわれ, 発生している幼雑草の間接的除草が行なわれることにな る。

以上のようにマルチや耕起によって, 雑草発生はかな り抑えることが可能となるが, 完全に防除できることに はならない。

雑草害としては, とくに幼木期の茶園で夏期メヒシバ の遮蔽によって生育が阻害されたり，水分の争奪による 生育障害がしばしば見受けられる。また成木茶園の場合 ヘクソカズラ, ヒルガオなど蔓性の雑草が摘採面にでて, 摘採葉に混じることによって, 茶の品質（香り）を著し く損なうことがある。さらに, 新開園地の雑木林, 草地, 竹林などに接する固場では周囲から侵入するササ類, チ ガヤ, ヤブガラシ, ヒルガオ, ヘクソカズラなどは防除 
が困難であることから，短期間に茶園を荒廃させるなど 実害を及ぼすものである。

\section{4. 雑草防除技術}

\section{（1）現在までの発展経過}

前述したように，茶の栽培では多面的な効用をもって 古くかららね間へわら，山草などのマルチが行なわれ， これに手除草を加えることによって防除してきた。

化学薬剤を使っての除草は，大正末期から昭和の初期 にかけて塩素酸加里を用いての除草効果が，茶業試験場 で検討されたに過ぎない。しかし，第二次大戦後に出現 した 2, 4-D は茶園にも試験され, 1949年以降はフェノキ シ系除草剤である $\mathrm{MCP}, 2,4,5-\mathrm{T} ， 2,4-\mathrm{PS}$ ，尿素系の $\mathrm{CMU}, \mathrm{DCMU}$ ，カーバメート系のIPC，Cl-IPC，ト
リアジン系のCAT, 或はフェノール系のPCPについて 検討がなされ，1970年ころにはパラコート，DCPA・ NAC（ワイダック）など，あるいは種々の混合剤も加 わって除草剤の適用試験が盛んとなった。

現在，茶園用の除草剤として登録されているものは第 3 表のとおりである。

\section{(3) 現在の雑草防除技術}

前項で述べたように, 現在の雑草防除は成園において は，マルチを中心に雑草の抑制をすることでおおかたの 解決をみているが，幼木園ではマルチ，除草剤散布，手 除草を組合せて行なっている。この場合マルチに必要な わらや山草は $10 \mathrm{a}$ 当り成木園では $500 \mathrm{~kg}$, 幼木園では 1 $\mathrm{t}$ に及ぶため, 経営面積の全体に十分な敷草を施すこと は困難となり, 幼木園では株元保護程度に施し, 裸地部

第 3 表 茶園用登録除草剤（1986年11月31日現在）

\begin{tabular}{|c|c|c|c|c|c|}
\hline 一般名·剂型 & 対象雑草 & 処 理 時 期 & 処理量 (10 a 当り) & 処理法 & 適用場所・注意事項 \\
\hline DCMU粒剂 & 畑地一年生雑草 & \begin{tabular}{|l} 
雑草発生前 \\
～発生開始
\end{tabular} & $7.5 \sim 10 \mathrm{~kg}$ & |茎葉兼土壌 & \\
\hline パラコート液剤 & 畑地一年生雑草 & $\mid \begin{array}{l}\text { 摘採 } 7 \text { 日前まで雑 } \\
\text { 草生育期 }\end{array}$ & $200 \sim 300 \mathrm{ml}$ & 茎莱 & $\begin{array}{l}\text { ○パラコートの使用回数 } 3 \text { 回以内とする } \\
\text { ○毒物につき取り扱い注意 }\end{array}$ \\
\hline CAT水和剤 & 畑地一年生雑草 & 雑草発生前 & $150 \sim 300 \mathrm{~g}$ & 土壤 & $\begin{array}{l}\text { O砂壤土〜埴士 } \\
\text { ○沖積土あるいは砂壌土の場合薬量を減ら } \\
\text { 寸 }\end{array}$ \\
\hline \multirow[t]{2}{*}{ MCC粒剂 } & \multirow[t]{2}{*}{ 畑地一年生雑草 } & 春季雑草発生前 & $4 \sim 5 \mathrm{~kg}$ & \multirow{2}{*}{ 土 袞 } & \\
\hline & & 夏季雑草発生前 & $6 \sim 8 \mathrm{~kg}$ & & \\
\hline \multirow{2}{*}{ トリフルラリン乳凮 } & \multirow{2}{*}{ 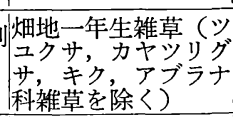 } & \multirow{2}{*}{$\begin{array}{l}\text { 二番茶登芽前およ } \\
\text { 前 }\end{array}$} & $200 \sim 300 \mathrm{ml}$ & 土壊混和 & \\
\hline & & & $300 \sim 400 \mathrm{ml}$ & 土塨表面 & \\
\hline トリフルラリン粒剤 & & \begin{tabular}{|l|} 
一番茶発芽前およ \\
び摘採後雑草発生 \\
前
\end{tabular} & $4 \sim 6 \mathrm{~kg}$ & $\begin{array}{l}\text { 土壌表面ま } \\
\text { たは混和 }\end{array}$ & 同 \\
\hline ジクワット液剤 & 畑地一年生雑草 & $\begin{array}{l}\text { 摘採 } 7 \text { 日前まで雑 } \\
\text { 草生育期 }\end{array}$ & $800 \sim 1,000 \mathrm{ml}$ & 茎葉 & \\
\hline
\end{tabular}

第 4 表 定植から成園までの除草労力（10 a 当り）（静岡県茶業試験場富士分場）（未発表）

\begin{tabular}{|c|c|c|c|c|c|c|c|c|c|c|c|c|c|c|c|}
\hline \multirow{2}{*}{ 年 } & \multirow{2}{*}{\multicolumn{2}{|c|}{ 項 }} & \multirow[t]{2}{*}{ 目 } & \multicolumn{3}{|c|}{ 手 除 草 } & \multicolumn{3}{|c|}{ 中耕機除草 } & \multicolumn{3}{|c|}{ 除草剂散布 } & \multicolumn{3}{|c|}{ 計 } \\
\hline & & & & 時 & 間 & 回 & 時 & 間 & 回 & 時 & 間 & 回 & 時 & 間 & 回 \\
\hline \multirow[t]{8}{*}{ 定 } & 植 & & 年 & & 17.6 & 3 & & 7.9 & 2 & & 4.3 & 4 & & 29.3 & 9 \\
\hline & 2 & 年 & 目 & & 42.1 & 5 & & 2.4 & 1 & & 3.5 & 3 & & 47.9 & 9 \\
\hline & 3 & 年 & 目 & & 41.2 & 8 & & - & - & & 5.8 & 5 & & 47.0 & 13 \\
\hline & 4 & 年 & 目 & & 36.6 & 7 & & 2.3 & 1 & & 3.5 & 3 & & 42.4 & 11 \\
\hline & 5 & 年 & 目 & & 10.5 & 3 & & - & - & & 3.5 & 3 & & 14.0 & 6 \\
\hline & 6 & 年 & 目 & & 15.0 & 3 & & - & - & & 3.5 & 3 & & 18.5 & 6 \\
\hline & 7 & 年 & 目 & & 11.5 & 4 & & - & - & & 2.3 & 2 & & 13.8 & 6 \\
\hline & 8 & 年 & 目 & & 10.5 & 3 & & - & - & & 3.5 & 3 & & 14.0 & 6 \\
\hline
\end{tabular}


分は除草剤散布ないし手除草により防除するのが通例で ある。

定植から成園に至るまでの除草方法と除草労力につい て一事例を第 4 表に示す。

これからもらかがえるように，定植年では茶園造成に あたって，深土が表層に露出されるため雑草発生は少な く, 除草回数, 労力ともに少なくてすむ。しかし， 2 年 目からは草種, 草量ともに増加することから除草回数, 労力は急増し, チャが生長して裸地部分が少なくなる 4 年目ころまでつづく。 5 年目ころになると，裸地部分が 少なくなるのに伴って, 除草労力は減少する。以後成園 に至っても同じ程度 ( $10 \mathrm{a}$ 当り10数時間) となる。除草
鼡散布の機会はあまり多くなく, 主として農道，法面に 発生する雑草に年 $2 \sim 3$ 回茎葉処理剤と土壤処理剂を混 合使用している。

うね間に除草剤を使用するのは定植 3 年目ころまで, 5 月下旬一番茶摘採後と 7 月ころの年 2 回程度土壤処理 剤による雑草発芽抑制を主目的に茎葉処理剤を混合して 散布している。

\section{（3）除草剤による雑草防除体系}

成木園における雑草防除は, 茶園の生産性を大きく左 右するほどのものではないが, 幼木園では早期成園化の 個別技術の一つとして大きな意義をもっている。特に定 植当年から 2 年目くらいまでのチャの生育の良否が問題

第 5 表 茶園除草剤使用基準（静岡県, 1986年度）

\begin{tabular}{|c|c|c|c|}
\hline 対象雑草 & $\begin{array}{l}\text { 使用薬戍执よび } \\
10 \text { a 当り使量 }\end{array}$ & 使用時期 & 使用方法および注意事項 \\
\hline $\begin{array}{l}\text { イネ科雑草 } \\
\text { 広葉雑草 }\end{array}$ & $\begin{array}{r}\text { CAT水和剤 } \\
(50 \%) \\
100 \sim 150 \mathrm{~g} \\
\text { CAT粒剤 } \\
(1 \%) \\
8 \mathrm{~kg} \\
\text { トリフルラリン乳剤 } \\
(44.5 \%) \\
300 \sim 500 \mathrm{ml} \\
\text { トリフルラリン粒剤 } \\
(2.5 \%) \\
4.0 \sim 5.0 \mathrm{~kg}\end{array}$ & 雑草の発芽前後 & 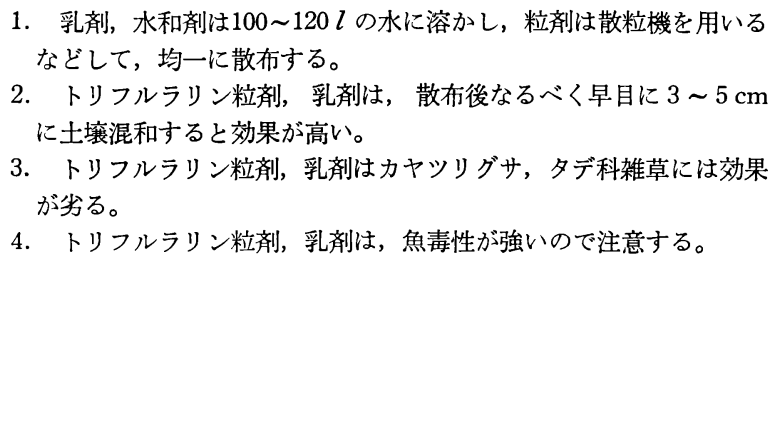 \\
\hline $\begin{array}{l}\text { イネ科雑草 } \\
\text { 広葉 雑 草 } \\
\text { (ツュクサ, } \\
\text { タデ科を除 } \\
\text { く) }\end{array}$ & $\begin{array}{r}\text { パラコート液剤 } \\
(24 \%)\end{array}$ & 雑草生育期 & $\begin{array}{l}\text { 1. 作業の際は必ずゴム製の手袋や防護メガネ, マスクを着用し, 薬 } \\
\text { 液を吸わないように注意する。 } \\
\text { 2. パラコート液剤は毒物なので, 保管, 管理や取扱いには十分注意 } \\
\text { する。 }\end{array}$ \\
\hline
\end{tabular}

第 6 表 除草方法別労働時間 (10 a 当り) (1971) (小幡)

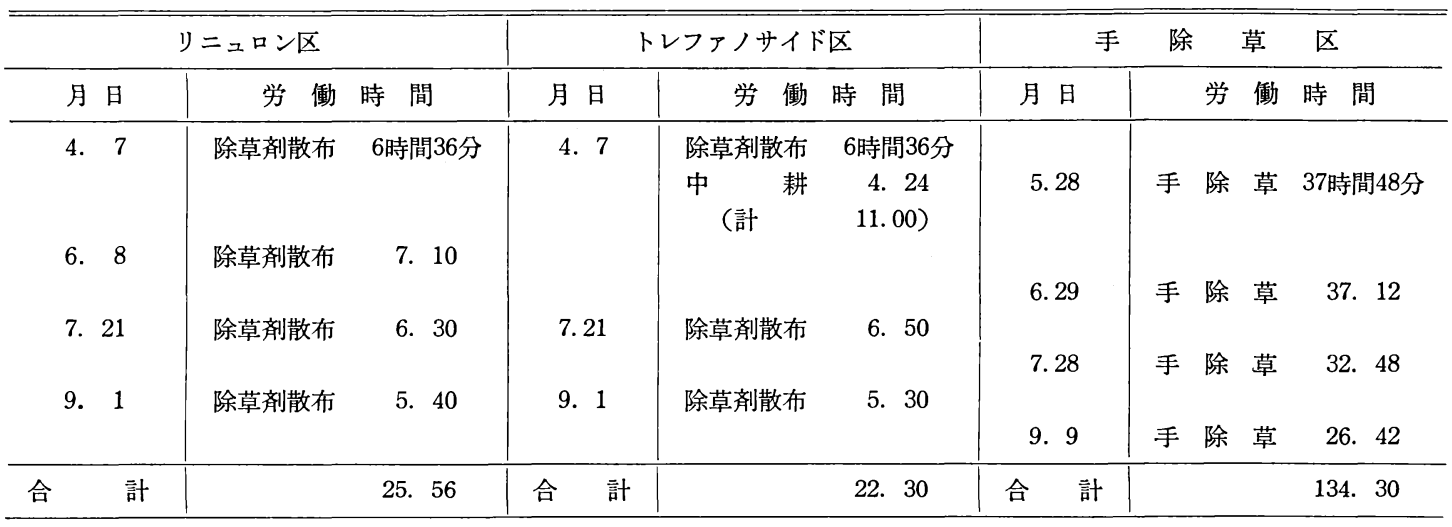


であるだけに，このころの雑草防除は重要であり，しか も事例で示したように, 年間 $10 \mathrm{a}$ 当り 40 数時間を要する ので, 除草剤散布による省力化が必要である。現在静岡 県における茶園の除草剤使用基準は第 5 表に示すとおり である。

第 6 表はいささか古い成績であるが，これらの除草剤 を組合せて使用体系を実証したものであるが，手除草と 比較して大幅な省力が可能となっている。

\section{5. 雑草防除上の問題点と今後の研究課題}

茶園での省力的かつ安定的な雑草防除の方法は除草剤 を合理的に使用することであろう。現在除草剂使用に当 って問題となることは, 茥葉処理剤散布に際してチャに 飛散して薬害を生ずることである。幼茶樹の場合その薬 害は致命的なものであり，摘採前の新葉に付着すること は言うに及ばない。そのようなことから, 除草剤散布に は噴口部分に飛散防止器具をつけて行なっているが，な お問題を生ずる機会が多い。

したがって, 先ず選択性の茎葉処理剤の開発が必要で ある。さらに, 宿根性雑草に対する効果的な処理剤の開 発も必要である。特にササなどの周辺雑草の侵入に対し
ては, 現在の茎葉処理剤をもってしても安定的な防除効 果を期待することができない。

以上, 茶園における雑草防除の現状と問題点について, そのあらましを述べた。茶園の性格上雑草防除は一般的 には，茶業経営上極めて重要な技術とは言えないにして も，幼木園管理の場面ではかなり重要視しなければなら ない課題である。さらに, 自立経営確立の面からは, 茶 園規模拡大にともなうて，その省力化は重要さを増すも のであると思われる。

本稿を執筆するに当ってご指導をいただき，多くの資 料を提供いただいた農水省野菜・茶業試験場青野英也博 士に深くお礼申し上げる。

\section{参 考 文 献}

1）青野英也・中山 仰（1949）：茶園の雑草目録. 農林省茶 試茶技研創刊号, $37 \sim 42$.

2）小幡兼男 (1973)：牧之原南部地域の茶園雑草について. 静岡茶試研究報告 No. 5, 35 53.

3）小幡兼男（1971）：幼木茶園雑草防除について. 静岡県茶 業試験普及資料.

（1986年12月 22 日受理） 